\title{
INSTITUTIONAL AND LEGAL MECHANISMS FOR PROTECTION OF THE RIGHTS OF UKRAINIAN MINORITY IN THE WARMIA AND MAZURY REGION
}

In 1918, after Poland regained independence, Poles constituted only $68 \%$ of all citizens; Jews, Germans, Ukrainians and Belarusians constituted several million national minority groups with their own cultural, social and political life. The disaster of World War II, the Holocaust and territorial changes after World War II meant that Poland lost part of its population. The borders of the Polish state which lost $1 / 3$ of their territory in the east, changed, moving west within the borders from the Oder to the Bug. According to the regulations, the Belarusian, Lithuanian and Ukrainian minorities had no right to repatriation, with the exception of the Jewish population. Part of this population remained in the Bieszczady Mountains and around Białystok. The German minority (3.2 million of Germans) was displaced from the Western Territories. Social relations changed radically. The indigenous people were considered Polish. The problem of the German minority was considered to be solved.

In the post-war Poland, a relatively uniform society was formed, in which national minorities accounted for $2-3 \%$ of the total population. In Poland, changes in the protection of the rights of national minorities occurred at the turn of the $1980 \mathrm{~s}$ and 1990s. Issues related to the protection of the rights of persons belonging to national minorities became an important milestone in building democracy in Poland (Łodziński, 1998). On January 6, 2005, the Polish parliament adopted The Act on National and Ethnic Minorities and on Regional Language (Dziennik Ustaw, 2005). Pursuant to Article 2 (1), a group of Polish citizens is considered to be national minority if it jointly meets the following conditions: it is less numerous than the rest of the population of the Republic of Poland; it is significantly different from other citizens of the country in terms of language, culture or tradition; it strives to preserve its own language, culture or tradition; it is aware of its own historical national community and is determined to express and protect it; the ancestors of minorities had to live in the present territory of the Republic of Poland for at least a hundred years and identify themselves with a nation organized in their own state. According to the Law, the following minorities are recognized as national minorities: Belarusian, Czech, 
Lithuanian, German, Armenian, Russian, Slovak, Ukrainian, Jewish. This law also defines the concept of ethnic minorities, which includes a group of Polish citizens who meets the same conditions as a national minority, except the last condition, because the ethnic minority does not identify with a nation organized in its own state. They include Karaim, Lemko, Roma, and Tatar.

The highest-order act, regulating the rights of national minorities in Poland, is the Constitution of the Republic of Poland (Konstytucja..., 1997). The rights of these minorities have been formulated in Article 35 of the Constitution (Konstytucja..., 1997). It should be emphasized that, paragraph 1 of Article 35 of the Constitution refers to the obligations of the state towards persons belonging to national minorities (Janusz, 1998: 58; 2001: 117), while paragraph 2 of that article states that „National and ethnic minorities have the right to create their own educational, cultural and institutional establishments for the protection of their religious identity and to participate in the resolution of matters concerning their cultural identity."

Research on the initiatives of self-government of the Warmia and Mazury Region for the equal treatment of national minorities (including Ukrainian national minority) is an important voice in the discussion on the policy of eliminating inequalities in Polish society. The attitude of the ruling majority to national minorities is a litmus test of democracy.

Scientific explorations were guided by the following research hypotheses: 1) national minorities in Warmia and Mazury including Ukrainian national minority are active and enrich Polish culture; 2) state administration authorities were interested in the activities of national minorities before the creation of local self-government in Poland (1999); 3) the self-government authorities of the examined region of Poland coming from leftist and liberal groups and the people's movement, support the activities of national minority organizations; 4) national minorities, including Ukrainian national minority, positively evaluate the existing support for their actions by local self-government and state administration; 5) Poland's integration into the European Union had a positive impact on the implementation of the policy on national minorities; 6) the relevant practices for the protection of the rights of national minorities at the level of the Warmia and Mazury Region are effective and therefore can be implemented not only in other regions of the Republic of Poland but also in other states for solving ethnic problems.

In the preparation of the research, the basic literature on the studied issues was reviewed. The main research problems included questions: How is the Ukrainian national minority distributed in the studied region? What are the historical features of its development? What are the main forms of activity/communication used by the Ukrainian national minority in the Warmia and Mazury Region at the present stage of its development? What problems does it face and what are the possible ways of solving them? What are state and local government institutions working for national minorities in the studied region of Poland? What activities do these institutions undertake to ensure equal treatment of national minorities and provision for their rights? How are these activities assessed by organizations/representatives of the Ukrainian national minority?

The leading research method was the institutional and legal one. The research also contained the interviewing method as well as the focus group interview. This made it 
possible to identify the peculiarities, characteristics, legal principles and effectiveness of the work of the main state institutions in the field of securing the rights of national minorities, particularly the Ukrainian national minority, at the level of the Warmia and Mazury Region.

\section{TERRITORIAL DISTRIBUTION OF NATIONAL MINORITIES IN THE WARMIA AND MAZURY REGION}

The Warmia and Mazury Region was established on January 1, 1999 as a result of administrative reform. It included the lands of Warmia, Mazury and Powiśle. Warmia and Mazury were the southern part of former East Prussia. The region is characterized by the greatest national and ethnic diversity in Poland. National diversity is also superimposed by considerable religious diversity, which together creates features typical of the borderland community with its multicultural dimension. According to the estimates from associations of national minorities, minorities constitute about $7-8 \%$ of all inhabitants of the region (1.429 million).

After World War II, almost entire German population left Warmia and Mazury. The war contributed to the exodus of the inhabitants of Warmia and Mazury (out of 2.5 million in the autumn of 1944, 450,000 remained). About 120,000 Warmians and Masurians remained, and just as many Germans. The first post-war years brought mass settlement of people from central Poland and Warsaw $(200,000)$, (Sakson, 1998: 107116) repatriates from former Kresy (140,000), (Sakson, 1998: 116-128), Ukrainians as part of Operation Vistula (70,000) (Sakson, 1998: 128-140) and smaller groups: Belarusians, Lithuanians, Roma (about 10,000 in total) (Sakson, 1998: 140-153) - all data are from 1950. Such diversity of the incoming population brought many integration problems (Sakson, 1998: 113-115, 153-189).

Today the largest group are Ukrainians with about 75-80 thousand people; they mainly live in the northern part of the region (see: Наш вибір, 2019). One should note that there are still discussions about the size of the national minorities, including the Ukrainian national minority, in this region. According to official figures, there are 11,000 Ukrainians living in the Warmia and Mazury Region, however a number of Polish NGOs, scholars and government officials disagree with this estimate. For example, during the 5th Ukrainian-Polish Scientific Forum in May 2019, the representative of the Marshal of the Warmia and Mazury Region for National Minorities, Wiktor Leyk, stated that the General Directorate of Statistics incorrectly indicated the size of the Ukrainian national minority by lowering the real numbers. As evidence, the official mentioned the lack of a full survey research in Górowo Iławeckie and Lelkovo municipalities (pl: gmina).

The second largest group are Germans, with about 25-30 thousand people. Belarusians are a group of 4-5 thousand people, largely assimilated. ${ }^{1}$ A specific group are Roma, about 1,000, including 400 people in Olsztyn. In addition to these population groups, the Warmia and Mazury Region is inhabited by some Russian families, and

\footnotetext{
${ }^{1}$ A small group (25 people) operate in the Regional Council of the Belarusian Democratic Union.
} 
in the Olecko, Gołdap and Ełk counties, Lithuanian families, which, however, do not tend to organize. There are also about 4,000 Warmians and 6,000 Masuria, although the census does not support this data.

National minorities live compactly in different parts of the Warmia and Mazury Region. The northern part, from the border with the Kaliningrad Region of the Russian Federation to Olsztyn, is inhabited by Ukrainians (Sakson, 2014: 120-134). The most numerous clusters are to the north from Braniewo to Banie Mazurskie, but there are also clusters of this population in the central part of the region (Olsztyn and Mragowo). The distribution of this population is caused by internal migration over the past fifty years, but also by Operation Vistula, which was guided by the principle of settling Ukrainians in the north of the region, in the least inhabited border area. Germans live both in the cities and in the villages. They are scattered throughout the region. There is a large cluster in Olsztyn (about 4-5 thousand). Mixed marriages constitute a significant proportion of German families. Belarusians live in the northern and central parts of the region. A small group was forced to settle, others came from migration from the Białystok region. Roma were settled in the cities as a result of administrative activities in the 1950s. In Olsztyn there is a cluster of 400 Roma; several dozen families live in Ostróda and Ełk. Lithuanians have been living in the north-eastern municipalities (Banie Mazurskie and Dubeninki) for centuries. The traditional settlement of Russians is in the vicinity of Wojnowo and Ukta (Old Believers), the others live in larger cities of the region. Masurians and Warmians live in their historical areas. A lot of them reside in Olsztyn, the historical capital of Warmia.

\section{STATE AND LOCAL SELF-GOVERNMENT INSTITUTIONS OPERATING FOR THE BENEFIT OF NATIONAL MINORITIES IN THE WARMIA AND MAZURY REGION}

One of the most important initiatives of the state administration in the region was the appointment of a plenipotentiary for national and ethnic minorities and local initiatives in 1994. The governor of Olsztyn (called a Voivode) Janusz Lorenz (Democratic Left Alliance, SLD) appointed Wiktor Leyk from the family of Masurian activists for this function. ${ }^{2}$ It should be emphasized that councilors of the Warmian-Masurian Regional Assembly (called Sejmik) from the Freedom Union Club UW (then a coalition) and the Democratic Left Alliance (opposition), and especially the deputy chairman of the Sejmik Miron Sycz - director of the Ukrainian Secondary School in Górowo Iławeckie coming from this environment - showed interest in the issues of national minorities in 1999. The joint initiative of Miron Sycz and Wiktor Leyk supported by the conclusions of associations of the German, Ukrainian and Belarusian minorities

${ }^{2}$ The tasks of the representative were formulated as follows: "1. Implementation of the state and regional policy represented by the governor for national, ethnic and religious minorities aimed at harmonious coexistence of a nationally and ethnically diverse society. 2 . Supporting the initiatives and aspirations of national minorities residing in the region aiming at their full and real equality in society as Polish citizens." Until January 1, 1999, the regions in Poland were managed by government administration. 
led to the establishment of the Committee for National and Ethnic Minorities in the Regional Assembly in March 1999. ${ }^{3}$ Its first composition ${ }^{4}$ included representatives of all council clubs. In the Statute of the Warmia and Mazury Region, the tasks of the Committee were formulated as follows: "matters related to consideration of the needs and initiatives of national and ethnic minorities, popularization of culture and language, integration and cooperation for the development of the region" (Załącznik do Uchwały, 1999). Representatives of all national minority associations were invited to participate in the inaugural meeting of the Committee (they participate in the work of the Committee as invited guests). The Committee meets at least once a month. Its outreach meetings are also organized. Now the chairman of the said Committee of the Warmia and Mazury Region is Jarosław Słoma from the Civic Coalition (KO), which exercises power jointly with the Polish People's Party (PSL) in this term of office of the regional council. ${ }^{5}$ The deputy constantly emphasizes the thesis about the multinationality of the region, the need to preserve its unique climate for the development of all national minorities of Warmia and Mazury. "We need to support national minorities in Poland, in the regions," says J. Słoma, "if we want other states to support the Polish diaspora in the world" (Лоза, 2019).

As a result of the change of the ruling coalition in the Regional Assembly (SLD, UW, PSL), on October 22, 1999, the new chairman (called Marshal) - Andrzej Ryński from SLD - appointed Wiktor Leyk as the Representative for National and Ethnic Minorities. His tasks were specified in the Organizational Regulations of the Marshal's Office. He was to represent local self-government authorities for national minorities maintaining permanent contacts with them, support cultural and educational initiatives, popularize the achievements of minorities and cooperate with the Committee for National and Ethnic Minorities of the Regional Assembly (Załącznik do Uchwały, 2020: paragraph 43).

The most important achievements of the Warmian-Masurian Regional Assembly in the matters of national minorities include: ${ }^{6}$ establishing full cooperation with all associations and centres of national and ethnic minorities within the enlarged region; analysis and formulation of a catalog of minority needs and expectations; full knowledge of the types of cultural, educational and social activities of minority communities; close and substantive cooperation with the Committee for National and Ethnic Minorities of the Parliament of the Republic of Poland and the joint Committee of the Government and National and Ethnic Minorities; establishing friendly cooperation with municipalities and self-governments inhabited by larger clusters of minorities and cultural initiatives on their behalf (also see: Astramowicz-Leyk, 2016).

${ }^{3}$ The committee has been operating until now and is the only Committee of this kind at the level of a Regional Assembly in Poland.

${ }^{4}$ In the current composition of this Committee there are no representatives of the Law and Justice Party, which is in opposition in the Regional Assembly of the Warmia and Mazury Region.

${ }^{5}$ After the local self-government elections in 2018, the Committee for National and Ethnic Minorities of the Warmia and Mazury Region includes, besides the chairman: E. Adamczyk - deputy chairman of the Regional Assembly (PSL), T. Astramowicz-Leyk - chairman of the International Cooperation Committee (KO), Z. Homza - deputy chairman of the Regional Assembly (KO) and M. Sycz - deputy marshal of the region (KO).

${ }^{6}$ Information from the Warmia and Mazury Region Marshal's Representative of May 10, 2016. 
Figure 1. Financial support for cultural initiatives of national minorities by the self-government of the Warmia and Mazury Region

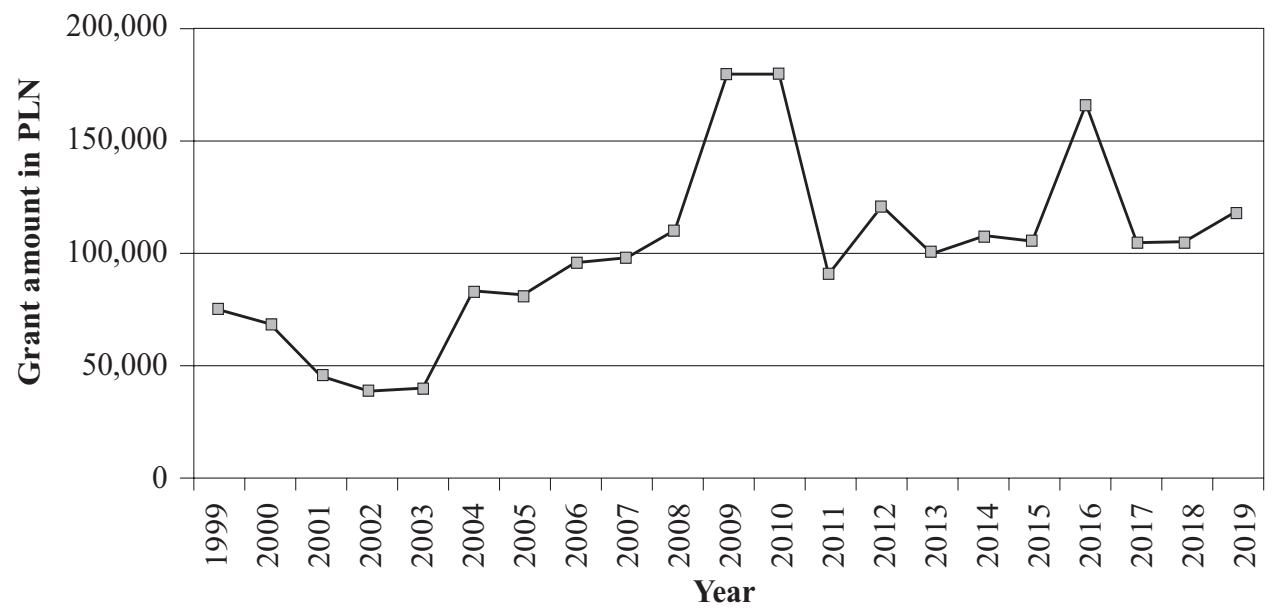

Source: Information on the activities of the Committee on National and Ethnic Minorities of the WarmianMasurian Regional Assembly of August 13, 2019.

Thus, the Warmia and Mazury is a multinational region due to its complex historical past. Such circumstances encourage the local authorities to develop local mechanisms of ensuring the rights of national minorities and harmonizing the interests of different social groups in order to avoid conflicts of ethnic origin. This is an important key to the sustainable development of the Warmia and Mazury Region. This undoubtedly actualizes the topic of the proposed research, the purpose of which is to determine the effectiveness of regional and local governmental institutions in the field of protection of the rights of national minorities and their development. The main criteria for determining effectiveness, in our opinion, can be: creating conditions by local authorities for the preservation of culture, language, and the exercise of religious and political rights of national minorities; providing financial support to national minorities; availability of media in minority languages and the like. This problem will be considered on the example of the Ukrainian national minority, which is the most numerous, institutionally organized and active in the Warmia and Mazury Region, has a long-lasting history and established mechanisms of interaction with local authorities and other national minorities.

\section{THE HISTORICAL GENESIS OF THE FORMATION OF THE UKRAINIAN NATIONAL MINORITY IN THE WARMIA AND MAZURY REGION}

It is quite natural that the largest autochthonous community of Ukrainians was formed in Poland among all the countries of the European Union, which is primarily explained by the change in the borders of both states in the historical past. The 2011 census recorded that 51,001 persons of Ukrainian descent resided in Poland, with 27,630 declaring Ukrainian roots as the only ones. Figures from some NGOs are some- 
what different; they claim that more than 250,000 Ukrainians lived in Poland in the early 1990s. In particular, the Association of Polish Ukrainians mentions from 350 to 500 thousand people of Ukrainian descent (Євтух, Трощинський, Попок, 2005: 43).

Today, the Ukrainian national minority comprising thousands of Ukrainians has fully integrated into the social and political life of Poland, is well represented in the fields of science, politics, education, government etc. As already noted, the largest concentration of Ukrainians in Poland is in the Warmia and Mazury Region. Together with the German minority, they demonstrate the highest degree of activity in the region (Sakson, 2011: 638-647). The largest number of Ukrainians (more than 50,000) appeared on the territory of the region, which is the former lands of East Prussia, as a result of Operation Vistula, which was carried out by the criminal communist regime in 1947. The deported Ukrainians came here from their native lands of south-eastern Poland, among others, from Pshemysl, Syanok and Beskids. The peasants constituted about 90 percent of the deported population (Domagała, 2009: 50). According to Polish researchers, the forced deportation of Ukrainians led not only to their considerable material losses, but, first of all, to the destruction of spiritual culture, the loss of the opportunity to study in their mother tongue, to visit national religious centers. Poland's state policy at the time was characterized by rigid directives aimed at the rapid assimilation of the Ukrainian national minority and the elimination of any possibility of preserving its national identity. It was even forbidden to use the word "Ukrainian" for the newly arrived migrants. Against that background, during the first decade of Operation Vistula, the Ukrainian community was closed, isolated from outside life, which, in fact, allowed to preserve the linguistic and ethnic identification of the group and to preserve it from external assimilation influences. The process of active assimilation of Ukrainians continued during 1947-1956. It is only after 1956 that the situation in Poland changed in favor of asserting the rights of the Ukrainian minority. During this period, the first centres enabling studying in Ukrainian appeared, schools with Ukrainian language of teaching began to open, Ukrainians were given the opportunity to practice their religion, that is an important factor in preserving national identity. In June 1956, the Ukrainian Social and Cultural Society was established and functioned until 1990 (Drozd, Halczak, 2010: 188-193). On the other hand, the democratization of Poland's political system during the 1980s and 1990s contributed to taking the issue of national minorities to a new level. In 1990, the Association of Ukrainians in Poland (AUP) was created. In the fall of that same year, its Olsztyn branch was established. In 1994, a Branch of the Association of Independent Ukrainian Youth in Olsztyn was established (its activity did not last long and currently it does not operate). Such events have undoubtedly influenced the development and transformation of the Ukrainian national minority, which now resides in the mentioned region.

In general, the activities of the Ukrainians of the Warmia and Mazury Region is concentrated around the Ukrainian centres in Poland. Officially, they number almost a thousand people. There are three such centers in the region: 1) Mazury (units: Banie Mazurskie, Węgorzewo, Wydminy, Giżycko, Kruklanki); 2) Elbląg (units: Elbląg, Pasłęk, Pieniężno, Lelkowo, Tolkmicko, Marzęcino, Ostaszewo, Stegna, Braniewo, Pęciszewo, Nowotki, Szymbory, Głębock, Jelonki, Jarzeń); 3) Olsztyn (units: Olsztyn, Dobre Miasto, Lidzbark Warmiński, Górowo Iławeckie, Bartoszyce, Stopki, Kętrzyn, 
Asuny, Gęsiki, Krelikiejmy, Srokowo, Mołtajny, Bajory Małe, Iława, Ostróda, Morąg, Reszel).

\section{THE CURRENT STATE OF THE UKRAINIAN NATIONAL MINORITY IN THE WARMIA AND MAZURY REGION}

Within the framework of the "State Policy for the Protection of the Rights of National Minorities: Experience of Ukraine and Poland" Ukrainian-Polish research project, a survey research of representatives of the Ukrainian national minority of the Warmia and Mazury Region was conducted. The goal of the study was to identify not only the specific features of the activities of the Ukrainian community but also to determine the level of effectiveness of local government institutions in securing rights and creating conditions for the development of national minorities.

The age category of the respondents is as follows: under $16-2.4 \%$; from 16 to $25-6.9 \%$; from 25 to $40-6.9 \%$; from 40 to $60-60.5 \%$; over $60-23.3 \%$. One can see that the majority of respondents were above middle age $(83.8 \%)$. This points to the low involvement of the younger generation in the activities of Ukrainian centres and confirms the thesis that modern migrants from Ukraine (mostly young and middleaged) are rather poorly integrated with the local Ukrainian community. This situation is, first of all, explained by migration preconditions. If the previous wave of Ukrainian migrants to the Warmia and Mazury Region (40-ies of the twentieth century) was provoked by political circumstances, then the modern one - by economic ones. Current migrants from Ukraine adhere to priorities derived from financial and domestic needs, which enhances their employment and, accordingly, limits their active participation in the life of the Ukrainian community of the Warmia and Mazury Region.

The majority of the respondents indicated that the Ukrainian community was cohesive, organized, holistic (81.4\%), and only $4.6 \%$ noted the existence of separate Ukrainian societies and unions that compete with each other (4.6\%). It is significant that none of the respondents described the Ukrainian community as isolated or hostile. Low motivation of the young generation of Ukrainians to participate actively in the life of the Ukrainian community; high degree of assimilation with the Polish population; existence of certain conditions that cause the Ukrainians to conceal their own national identity were also noted, which is largely explained by the complexity of inter-ethnic Ukrainian-Polish relations in the historical past.

Interviewed leaders of Ukrainian centers pointed to the peculiarities of the transformation of the Ukrainian national minority over the past decades in Warmia and Mazury. Positive changes include a change in professional affiliation, as today a significant part of Ukrainians have higher education, which has led to a change in the place of residence of Ukrainians, the accumulation of a large claster of Ukrainians in urban areas. This also has the effect of relative improvement of the political representation of the Ukrainian minority in the Polish authorities, mainly at the local level. On the other hand, changes that do not contribute to preserving national identity include a significant reduction in the use of the native (Ukrainian) language, the unsatisfactory condition of the Ukrainian-speaking environment as a whole as well as an increase in 


\section{Figure 2. Characteristics of the Ukrainian national minority of the Warmia and Mazury Region}

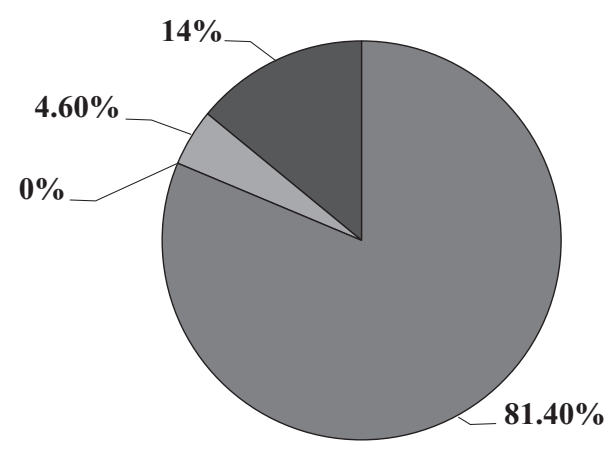

$\square$ Cohesive, organized, holistic

$\square$ There are separate Ukrainian societies and unions that compete with each other

Isolated, hostile

Other

Source: Authors' research based on the own survey within the framework of the "State Policy for the Protection of the Rights of National Minorities: Experience of Ukraine and Poland" conducted in 2019.

the assimilation of ethnic Ukrainians, provoked both by Ukrainian-Polish contradictions on the historical grounds and the desire of Ukrainians themselves to improve their social status in Polish society.

The most widespread forms of civic activity of the Ukrainian community in the Warmia and Mazury Region were singled out.

We can observe that the Ukrainian community is quite active in using traditional forms of self-organization - the church, as well as Ukrainian cultural societies. Religious affiliation is known to be an important component of preserving national identity. It should be noted that in the Warmia and Mazury Region there are two largest Greek Catholic parishes of Asuny and Kętrzyn which belong to the Węgorzewski Deanery. In total, there are 22 Greek Catholic and 11 Orthodox parishes in the Region. However, the latter, according to the respondents, do not recognize the formation of the Orthodox Church of Ukraine in 2019. Many Ukrainian communities either already have their own churches (Olsztyn, Giżycko etc.) or are in the process of building them, e.g. in Elbląg. This is important and means that Ukrainians are connecting their future life prospects with this Region. However, the number of church parishioners is decreasing, especially among the younger generation of Ukrainians. Mostly, such state of matter is a consequence of assimilation processes, which is also reflected in religious affiliation. On the other hand, nowadays, Ukrainians are free to profess their religion and adhere to national religious traditions, and local authorities are assisting this primarily by allocating land plots for the construction of Ukrainian churches.

Among other forms of activities of Ukrainians in Warmia and Mazury, one should mention the activities of Ukrainian schools and training centres, and learning Ukrainian language in schools. National minorities operating within the borders of the Republic of Poland are guaranteed the right to learn their native language as well as the right to study in that language. The act of the highest order regulating the rights of national minorities in Poland is the Polish Constitution. The constitutional principles of the state (Chapter I of the Constitution) establish Polish as the official language, but by referring to ratified international agreements, the right to use the mother tongue 
Figure 3. Forms of civic activity of the Ukrainian national minority of the Warmia and Mazury Region

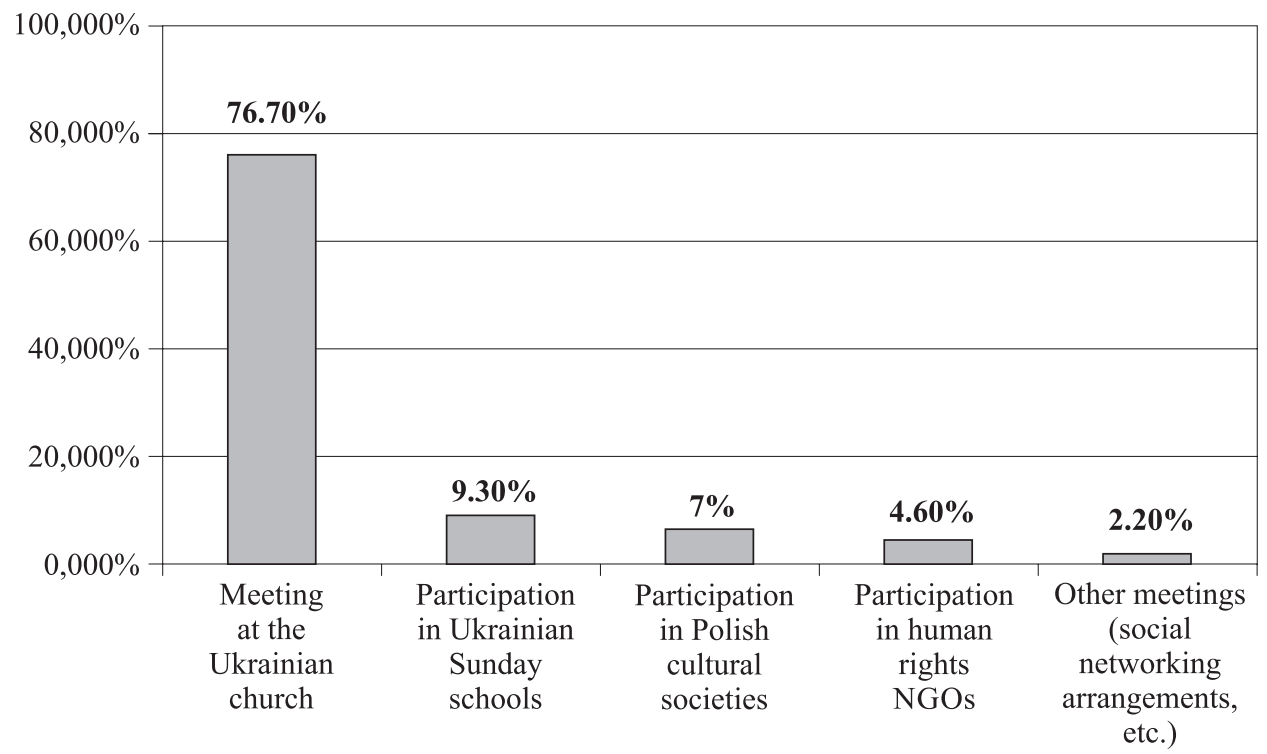

Source: Authors' research based on the own survey within the framework of the "State Policy for the Protection of the Rights of National Minorities: Experience of Ukraine and Poland" conducted in 2019.

by persons belonging to national minorities is granted. ${ }^{7}$ The rights of these minorities are more broadly formulated in art. 35 of the Constitution. ${ }^{8}$ It should be emphasized that paragraph 1 of Article 35 of the Constitution refers to the obligations of the state towards persons belonging to national minorities (Janusz, 1998: 58; 2001: 117) while paragraph 2 of the same article states that "National and ethnic minorities have the right to create their own educational and cultural institutions as well as institutions serving the protection of religious identity and participation in settling matters concerning their cultural identity."

The constitutional guarantees of the right of national minorities to education ${ }^{9}$ find their expression in earlier laws. The legal regulation of the right of national minorities to education is contained in the Act "On the Education System" of September 07,

${ }^{7}$ Article 27 of the Basic Law states that "In the Republic of Poland, the official language is Polish. This provision does not infringe upon the rights of national minorities arising from ratified international agreements."

${ }^{8}$ Article 35 (1) states that "the Republic of Poland shall ensure that Polish citizens belonging to national and ethnic minorities have the freedom to preserve and develop their own language, to maintain customs and traditions, and to develop their own culture." This part of Article 35 imposes an obligation on the Polish state to create both legal and political norms that favor people from national minorities to preserve and develop their native language, customs and traditions, as well as national culture.

${ }^{9}$ In the 1997 Constitution of the Republic of Poland, Article 35 (2) mentions national and ethnic minorities that they have rights, but this statement should be understood as the rights of individual persons belonging to national minorities, not groups. Although it will be easier to create an educational institution for people from a national minority when they create an association or foundation. 
1991 (Dziennik Ustaw, 1991). Article 13 of this Act states that "a public school enables students to maintain a sense of national, ethnic, linguistic and religious identity, in particular learning their language as well as their history and culture" (Dziennik Ustaw, 1991).

National minorities in Warmia and Mazury realize their right to education not only on the 30th anniversary of Polish freedom (see: Astramowicz-Leyk, 2002). Since 1956, there have been classes with Ukrainian language of teaching parallel to Polish classes in Banie Mazurskie. In the 2014/2015 school year, ${ }^{10} 200$ students learned Ukrainian at the lower secondary level. The greatest number (55 students) studied at the lower secondary school with the Ukrainian language of teaching in Górowo Iławeckie. Second place belonged to the school No. 3 with Ukrainian language of teaching in Bartoszyce. Lower secondary schools in Pieniężno and Lelkowo had 14 students each one. In turn, a total of 111 students learned Ukrainian at the secondary school level. Most Ukrainian students studied at the Ukrainian Secondary School in Górowo Iławeckie (106 students), and only 5 students at the Secondary School in Braniewo. In primary schools, 449 students learned Ukrainian. Most students were in the primary school (PS) named after Lesia Ukrainka with the Ukrainian language of teaching in Bartoszyce (81 students), over 20 students studied Ukrainian at PS in Giżycko, PS in Banie Mazurskie, PS in Pieniężno, PS in Górowo Iławeckie, PS in Nowica - Braniewski county, PS in the School Complex in Lelkowo. 51 children learned Ukrainian in pre-schools; most - 16 children - in primary school named after Lesia Ukrainka with Ukrainian language of teaching in Bartoszyce. 760 people studied Ukrainian in schools in the 2014/2015 school year which, in combination with pre-school departments, gives a total of 811 people. An interesting fact is that in the School Complex with Ukrainian language of teaching, 50 students came from Ukraine.

According to information from the Warmian-Masurian School Superintendent, in the school year 2018/2019, a total of 773 students learned Ukrainian as a national minority language (Pismo..., 2019), including six pre-school departments organized in primary schools. ${ }^{11}$ As for primary schools, as many as 67 schools teach Ukrainian as a national minority language. In already closed lower secondary schools, Ukrainian language was taught as a national minority language in 12 schools. On the other hand, at the secondary school level, Ukrainian language is taught only at the Ukrainian Secondary School in Górowo Iławeckie and at the secondary school in Braniewo.

From the presented data, one can conclude that there is a noticeable decrease in the number of students for whom schools undertake tasks aimed at maintaining the national and linguistic identity of students belonging to the Ukrainian national minority. Another problem that appears in teaching Ukrainian is whether and to what extent economic migrants arriving from Ukraine to Poland, including the Warmia and Mazury Region, will be interested in their children being taught Ukrainian, as this may possibly contribute to the increase in the number of students covered by learning this language.

${ }_{10}$ Data on teaching of Ukrainian in the school year 2014/2015 comes from information obtained from the Warmian-Masurian Board of Education in Olsztyn (see: Dane...).

${ }^{11}$ These are the schools in the Bartoszyce, Branievo, Giżycko (Wydminy), Kętrzyn (Drogosze and Mołtajny), and Ostróda (Morąg) counties. 
Therefore, there are conditions for learning Ukrainian or studying in Ukrainian. The local authorities do not create any obstacles for it and promote the development of Ukrainian schooling; however another issue is the progressive assimilation of Ukrainians, including the representatives of the last migration wave as well as insufficient support from the Ukrainian authorities for the process of learning Ukrainian by foreign Ukrainians.

In general, the Ukrainian national minority in Poland is known for its culture and national traditions, which are a significant contribution to the development of Polish culture. In the multicultural Warmia and Mazury Region, Ukrainians have the opportunity to develop and demonstrate their cultural heritage as well as maintain a stable connection with their homeland in this field and to cooperate with other national minority societies on this basis (see: Czetyrba-Piszczako, 2015). Thus, the respondents are pointing to the significant importance of cultural events (concerts, festivals, performances, conferences, etc.), such as: Days of Ukrainian Theater, festivals "Pid Spil'nym Nebom" ("Under the Common Sky"), "Barvy Ukrainskoii Kultury" ("Colors of Ukrainian Culture"), "E-Colomyia," "Nich Ivana Kupala" ("Ivan Kupala’s Night"), Days of Ukrainian Culture, regional Ukrainian fair "Z Maliovanoji Skryni" ("From a Hand Drawn Chest”), International Church Music Days, International Festival of Children's Folklore Circles of National Minorities, Shevchenkivsky Concerts, TV and radio festival "Kalinovy Mosty" ("Guelder Rose Bridges") etc. There are numerous dance and song groups in the region, including "Dumka," "Lisova Pisnia," "Dar Liubovi," "Suzir'achko," "Cheremosh," "Lemkivski Veselushki" and others. The Ukrainian cultural heritage is well received by the local population, which is important not only for preserving Ukrainian ethnicity or popularization of the cultural heritage of Ukrainians, but also because it is an effective instrument of soft influence that "works" to enhance the integration of Ukrainians into modern Polish society. And precisely, this tool, in our opinion, is quite effective for the formation of a positive image of the Ukrainian state in the Warmia and Mazury Region. Such an instrument is apolitical, therefore non-debatable, has an established institutional framework and does not require significant financial costs.

The state and prospects for the development of the Ukrainian community in the Warmia and Mazury Region depends on the intensity of participation of its representatives in various forms of public activity aimed at preserving national identity. We see that more than $80 \%$ of the respondents are systematically involved in various forms of activity (monthly, weekly). But every one in five Ukrainians participate in joint events very rarely - about once a year. Unfortunately, given the low involvement of young people in the life of Ukrainian community and strong assimilation processes, one can predict further decrease of this indicator. Therefore, opportunities for active social life for the preservation of national identity have been created and exist, however, because of these objective circumstances, not all members of the Ukrainian national minority benefit from them.

Co-operation of the Ukrainian community for preserving national identity also depends on the level of internal communication. Therefore, the respondents were asked to evaluate the quality of existing channels of internal communication of the Ukrainian community in the Warmia and Mazury Region according to the scale where 1 means an inadequate level of communication and 10 is the maximum level. Thus, $95.4 \%$ of 
Figure 4. Frequency of participation of Ukrainians in the Warmia and Mazury Region in various forms of public activity aimed at preserving national identity

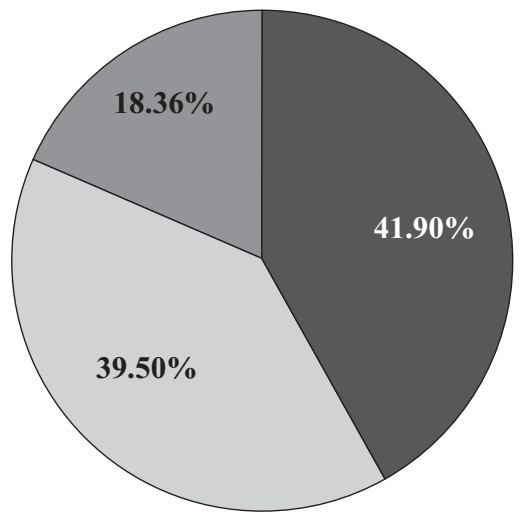

Often, once a week

Once a month

Seldom, once a year

Source: Authors' research based on the own survey within the framework of the "State Policy for the Protection of the Rights of National Minorities: Experience of Ukraine and Poland" conducted in 2019.

respondents answered that the level of communication within the Ukrainian community was sufficient and maximum, indicating figures from 5 to 10 . It is worth noting that more than a quarter of respondents $(25.7 \%)$ indicated the maximum level of communication (figure 10). Only $4.6 \%$ of respondents described the level of communication as inappropriate (figures 1-4).

Figure 5. Assessment of the level of internal communication of the Ukrainian national minority of the Warmia and Mazury Region

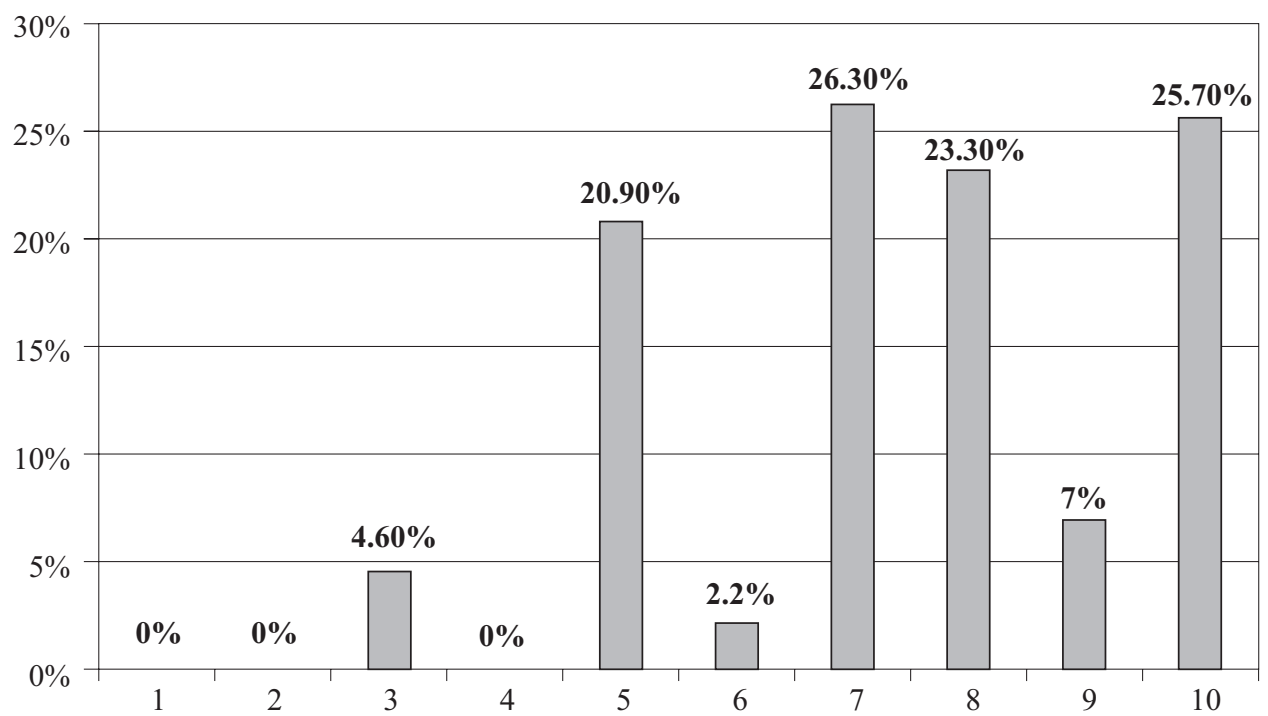

Source: Authors' research based on the own survey within the framework of the "State Policy for the Protection of the Rights of National Minorities: Experience of Ukraine and Poland" conducted in 2019. 
In addition, the respondents were asked about the means (channels) by which they were informed about various aspects of life of the Ukrainian community in the Warmia and Mazury Region.

Figure 6. Sources of information on various aspects of life of the Ukrainian community in the Warmia and Mazury Region

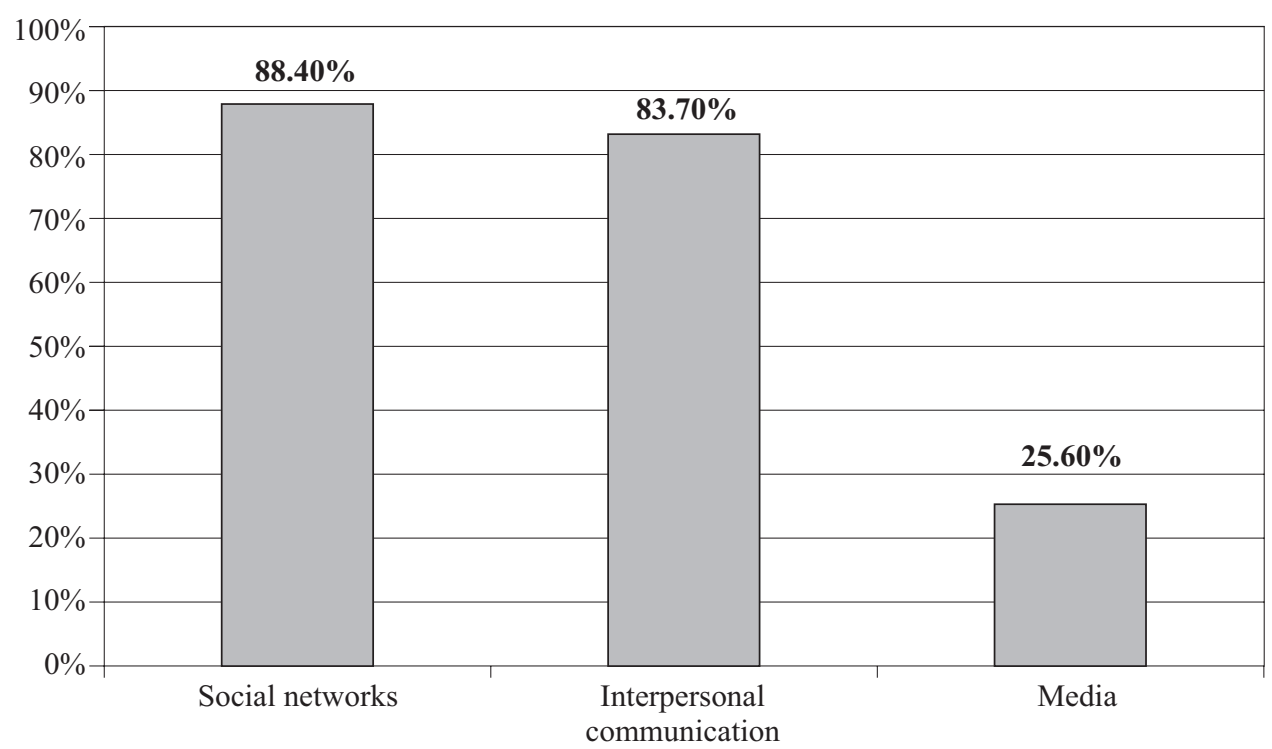

Source: Authors' research based on the own survey within the framework of the "State Policy for the Protection of the Rights of National Minorities: Experience of Ukraine and Poland" conducted in 2019.

Among the other options expressed, there were mostly answers that Ukrainians of the Region often used such channels of communication as a church and local branches of the Union of Ukrainians in Poland. The presence of the Ukrainian minority in the local information space with the use of their native language is important. In the region, the newspaper of the Ukrainian community of Poland "Nashe Slovo" is distributed, and in Górowo Iławeckie there is an editorial office of the "Blagovist" magazine. Since 1958, a Ukrainian radio program has been broadcast, and since 2011 it has been broadcast daily for 30 minutes on the radio waves of "Radio Olsztyn." Every other Tuesday on regional television, Ukrainian News are on air for 30 minutes.

An effective policy on national minorities results in the integration with representatives of other national minorities or a title nation; it significantly minimizes the emergence of ethnic conflicts which are very difficult to resolve. Since Warmia and Mazury are multinational, it is of particular importance to clarify "Ukrainian national minority - other ethnic minorities" and "Ukrainian national minority - title nation' relationships." This issue is actualized in light of several points; firstly, the growth of nationalist movements in Europe, including Poland; secondly, information about the violations of the rights of national minorities, including Ukrainians (especially the current migration wave) in Polish media; and thirdly, the complexity of modern interstate relations between Ukraine and Poland, which have historical background. 
In order to find out about the peculiarities of the relations of the Ukrainian community with representatives of other national minorities, the question "Do you contact (communicate) with representatives (leaders) of other national minorities in the Warmia and Mazury Region in order to coordinate joint activities aimed at protecting and supporting national minorities in the region?" was asked. More than 58\% of respondents said "yes," while 41.9\% answered "no." It is noted that cooperation with German and Roma national minorities is particularly active. The actions of the local authorities are not aimed at isolating national minorities or creating artificial obstacles for their cooperation, but on the contrary, at promoting their cooperation. In this way, a positive non-conflict environment for the development of the multicultural land of Warmia and Mazury is formed which prevents the "ghettoisation" of certain national minorities. When asked, "Do the local authorities carry out a unified policy for different national minorities?," the respondents stated that, in fact, close cooperation between national minorities left no place for a double standards policy. There is no contradiction between ethnic minorities regarding the distribution of financial grants by local authorities. Since the German minority has substantial financial support from their homeland and the Roma minority has a special state program, they are well aware of the more complex financial situation of Ukrainians, in fact, deprived of financial support from the Ukrainian government.

The situation in the relations between the Ukrainian national minority and the title nation looks a little different.

Figure 7. Do you feel negative attitude towards yourself from the Polish population of Warmia and Mazury Region

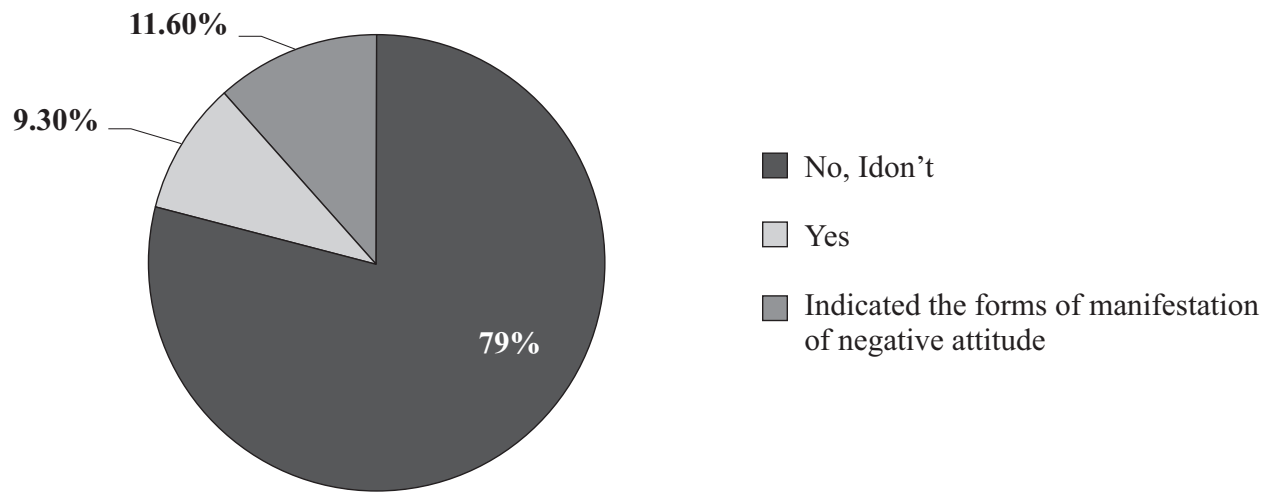

Source: Authors' research based on the own survey within the framework of the "State Policy for the Protection of the Rights of National Minorities: Experience of Ukraine and Poland" conducted in 2019.

It is worth noting that almost $12 \%$ of the respondents indicated the forms of manifestation of a negative attitude. These are answers such as "rarely, at work," "sometimes there are negative comments on the internet or in the press, as well as insulting signs on the streets," "I do not feel personally, but as a community - yes," "the current situation is significantly better than 30 years ago thanks to increased communication with the Polish population." It was noted that the wave of negativity was growing 
before the commemoration of important historical dates for Ukrainians, such as the memory of the victims of Operation Vistula, or by "throwing-in" negative information in the media concerning the debating historical issues of Ukrainian-Polish relations. So there is some tension which is explained, firstly, by the complex historical memory of both peoples, and secondly by the unresolved historical issues at the interstate level. On the other hand, the situation is not as critical as it was a few decades ago, but it is directly related to the common European trend - the spread of influence of nationalist movements in Europe. At the same time, none of the respondents indicated that the negative attitude towards Ukrainians was propagated by or derived from the actions of state, regional or local authorities.

To assess the attitude of local authorities to the Ukrainian community, the question was asked: "Do you feel support from the Polish authorities (local, regional) in the Warmia and Mazury Region as a representative of the Ukrainian community?" The overwhelming majority of respondents feel support (95.4\%). It is appropriate to mention the words of a well-known researcher of the Ukrainian diaspora in Poland, Bohdan Halczak, that a pattern is observed that where there are enough Ukrainians and they are well-organized, there is their greater support from local authorities (Halczak, 2010: $113-127)$. Only $2.3 \%$ of respondents do not feel support, and a small number note the deterioration or lack of such support.

Figure 8. Do you feel support from the Polish authorities (local, regional) in the Warmia and Mazury Region as a representative of the Ukrainian community

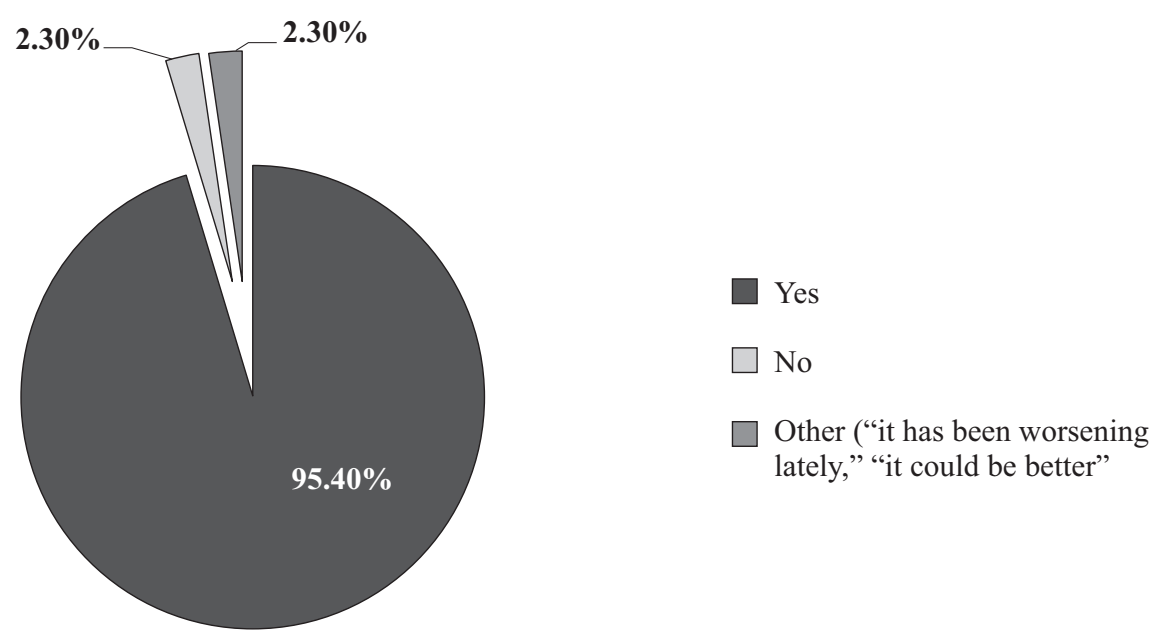

Source: Authors' research based on the own survey within the framework of the "State Policy for the Protection of the Rights of National Minorities: Experience of Ukraine and Poland" conducted in 2019.

To measure the level of support of the Polish authorities (local, regional) for the Ukrainian community in the Warmia and Mazury Region, an assessment scale ranging from 1 (no support) to 10 (maximum support) was selected. $81.5 \%$ of respondents indicated that support was above average, with figures ranging from 5 to 10 . Instead, $28 \%$ of respondents indicated average level of support (figure 5), and $16.3 \%$ described support as low (figures 1-4). 
When asked, "Do you consider the local and regional authorities' financial support for Ukrainian societies in the Warmia and Mazury Region sufficient," nearly $42 \%$ of respondents rated it as sufficient and medium.

Figure 9. Do you consider the local and regional authorities' financial support for Ukrainian societies in the Warmia and Mazury Region sufficient

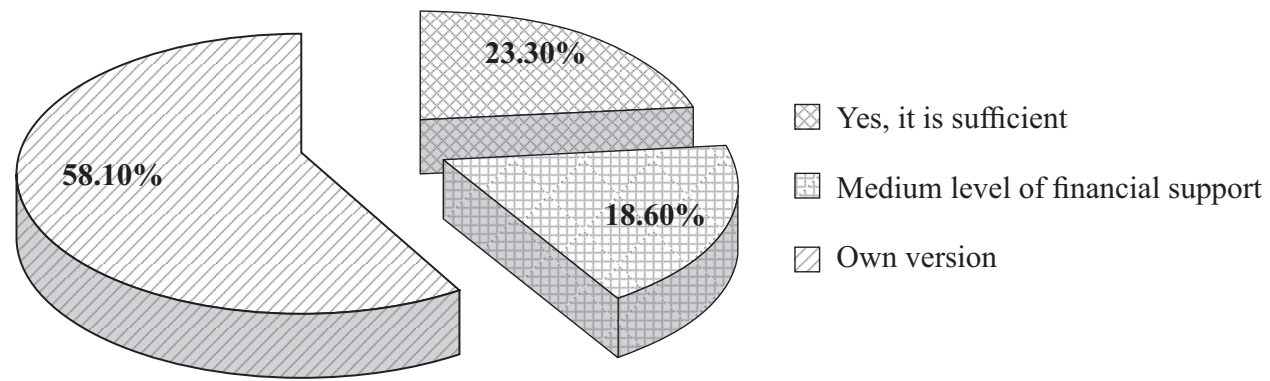

Source: Authors' research based on the own survey within the framework of the "State Policy for the Protection of the Rights of National Minorities: Experience of Ukraine and Poland" conducted in 2019.

By the way, during the Congress of Political Scientists in Poznan', professor of the University of Warmia and Mazury in Olsztyn Teresa Astramowicz-Leyk published the data of her research for 2016 and noted that the Ukrainian national minority then expected more funding from the regional authorities, since there was no financial support from the Ukrainian authorities at all. The current chairman of the National Minorities Committee, J. Słoma noted that in 2019, 40,000 PLN were allocated to competitions among minority NGOs, and the committe suggested that the Chairman of the Warmia and Mazury Region should significantly increase this amount. The deputy stressed that the government had significantly limited material support to national minorities, and no member of the Law and Justice Party had expressed a desire to work in the National Minorities Committee, which also indicated some national trends in the implementation of ethnopolitics.

When asked "How often do you, as a representative of the Ukrainian community, ask the Polish authorities (local, regional) to protect your rights, freedoms and meet your needs in the Warmia and Mazury Region?," the following answers were received: "often" - 9.3\%; "rarely" - 46,6\%; "never" - 41.9\%; "if necessary" $-2.2 \%$. Therefore, the prevailing view is that community representatives do not appeal or rarely appeal to representatives of the Polish authorities (local, regional) (88.5\%). Mostly, this mission is carried out by the leaders of the Ukrainian centres which is quite natural, since they are endowed with representative functions.

We would like to highlight the proposals of the leaders of the Ukrainian community which are directed to the representatives of the Polish authorities and, according to local Ukrainians, can contribute more to the development of the Ukrainian national minority in the Warmia and Mazury Region. The key proposals here were: 1) to increase the amount of Ukrainian airtime on television, radio, publications in the press; 2) to increase popularization of Ukrainian music, films, sports; 3 ) to create a regional center of Ukrainian culture; 4) to support educational projects, to found scientific centers which 
will facilitate joint research into history, and thus strengthen inter-state UkrainianPolish cooperation; 5) to create a museum of displaced persons of Operation Vistula in the region; 7) to invite qualified practitioners from Ukraine to work in cultural centers; 8) to simplify bureaucratic procedures in dealing with national minorities; 9) to increase the presence of Ukrainian topics (positive content, as emphasized ) in local media and on the Internet, etc. We see that a lot of proposals require not only significant initial investment but also large financial costs to support the ongoing functioning of such projects. Therefore, implementation of such proposals requires not only the efforts of the Polish authorities or resources from the Ukrainian community (information, organizational, personnel), but also considerable support from the Ukrainian government, first of all, financial, which is unlikely to date.

The heads of the centers were also asked to name the main benefits of the Polish policy on national minorities, including that at the level of the Warmia and Mazury Region. The following answeres were received: 1) a proper legal framework for the exercise of and respect for the rights of national minorities; 2) effective functioning of the Committee on National Minorities and the Marshal's representative of the region on national and ethnic minorities at the local level; 3) existing mechanism for co-financing/financing activities undertaken by the Ukrainian minority; 4) providing premises for the operation of Ukrainian centres; 5) political representation of the Ukrainian national minority at the local level.

Regarding the level of political representation, on October 21, 2018, elections were held in Poland to the self-governing bodies (called: gmina, poviat, sejmik, as well as wojt and burgomaster of cities). In total, 95 candidates - representatives of the Ukrainian community - ran for election in the country. Of these, 39 were victorious (Лоза, 2018a). Two Ukrainians became deputies of the Warmian-Masurian Regional Assembly: Miron Sycz mentioned above and Zbigniew Homza. These deputies headed the electoral lists of the Civic Coalition, created by the Civic Platform and Nowoczesna parties. In total, more than 15 representatives of the Ukrainian community work in the regional representative bodies of different levels (Лоза, 2018b). However, the level of political representation of the large Ukrainian community is still insufficient. This can be explained by the generally low level of political activity of Polish Ukrainian, which is justified by several reasons: the disperse nature of the Ukrainians' residence on the territory of the Republic of Poland, the confessionality of the Polish Ukrainians, the established negative stereotype of the Ukrainian among Polish population as well as too weak support from the "mother" state (Турчин, 2014: 155).

The Ukrainian leaders have noted some underdevelopment of Polish policy on national minorities at the regional level, lack of funding for the activities of the Ukrainian national minority as well as some difficulties with Ukrainian radio broadcasting observed over the last two years, which relate to the introduction of information censorship (the show is translated into Polish and after reviewing it the editor makes the decision to publish this or that information). It was also noted that the treatment of national minorities depends significantly on the political situation or historical contradictions existing at the interstate level between Ukraine and Poland.

Within the Ukrainian national minority, the actions of the authorities related to the protection of the rights of national minorities are often linked to the accession of the 
Republic of Poland to the EU. The question "Has Poland's integration with the EU influenced its policies for national minorities?" was answered that most of the positive practices in this area are, in fact, derived from the integration of the Republic of Poland into the EU. Poland's entire legislative base is in line with EU legislation on the rights of national minorities. This allows Ukrainians to better represent their heritage, which has generally improved the attitude of Polish society to the Ukrainian national minority.

As representatives of the Ukrainian national minority repeatedly pointed to the low presence of Ukrainian authorities in solving their problems, it was appropriate to diagnose the state of interaction/communication between the Ukrainian community of the Warmia and Mazury Region and Ukraine since many needs of local Ukrainians may be met only with the support of the Ukrainian authorities.

In order to find out about the support of Ukrainians in the region by the Ukrainian authorities, the first question was asked about the evaluation of the work of the Consulate of Ukraine in Gdansk with the Ukrainians of the Warmia and Mazury Region, according to the scale where 1 stands for "no support," and 10 - "maximum support and assistance." Therefore, $34.8 \%$ of respondents indicated that support was above average, indicating figures from 5 to $10.48 .9 \%$ described support as low (figures 1 to 4 ). Of these, $37.4 \%$ of respondents indicated a very low level of support (figure 1).

Figure 10. Evaluation of the effectiveness of consular work with the Ukrainian national minority of the Warmia and Mazury Region

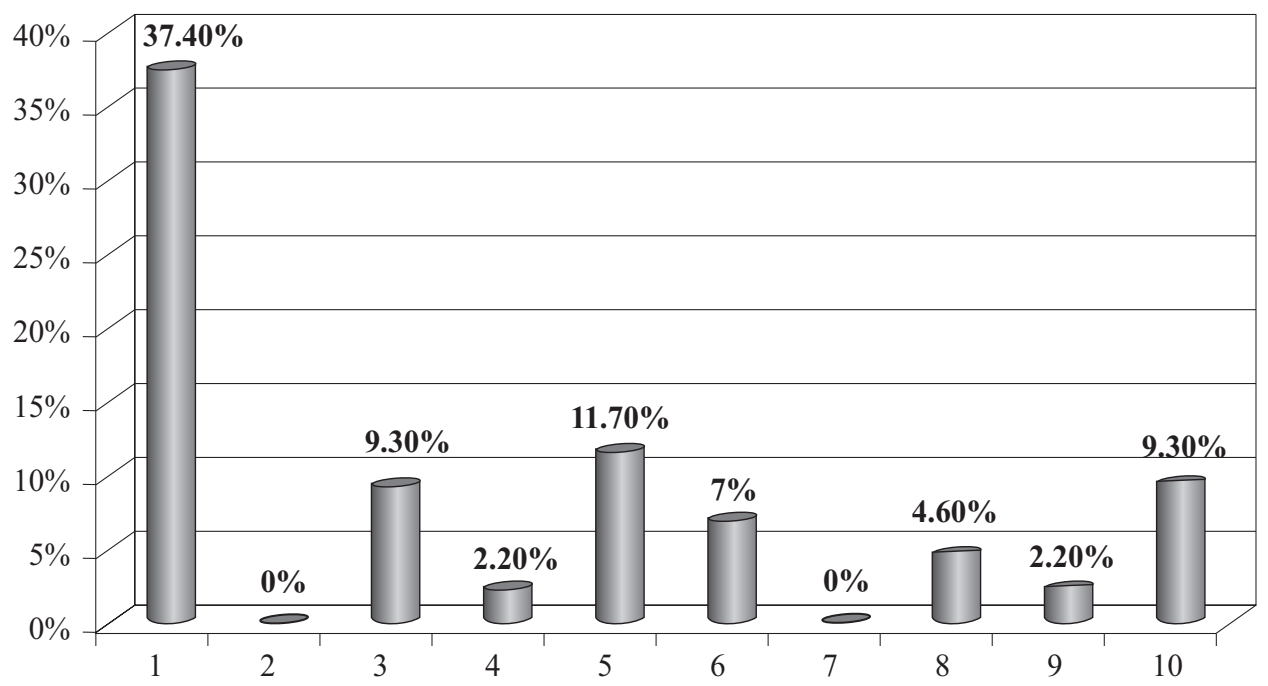

Source: Authors' research based on the own survey within the framework of the "State Policy for the Protection of the Rights of National Minorities: Experience of Ukraine and Poland" conducted in 2019.

More than $16 \%$ of respondents said they did not seek support from the consulate. This situation is explained by the fact that not all local Ukrainians are in contact with the Consulate in Gdańsk due to objective circumstances, although the leaders of Ukrainian centres all without exception maintain contacts with the Consulate. How- 
ever, they pointed out the lack of coordination efforts of the Consulate. In our opinion, the situation can be improved by raising the status of the Gdańsk Consulate to the level of General which will allow to increase the staffing and funding of this structure in the field of work with national minorities.

When asked what issues the Ukrainian authorities should pay more attention to when working with the Ukrainian community of the Warmia and Mazury Region, the following answers were received: 1) development of cultural ties with the Motherland $-83.7 \%$; 2) financial support of Ukrainian societies in the region $-69.8 \%$; 3 ) creation of Ukrainian cultural centers and schools in the region $-62.8 \%$; 4 ) protection and securing of the rights of labour migrants $-39.5 \%$; 5) support for joint research by universities of region and Ukraine $-34.9 \%$; 6) recognition of Ukrainian diplomas and degrees in the region - 27.9\%; 7) ensuring the political (electoral) rights of Ukrainians $-20.9 \%$. As we can see, the respondents are most concerned about the development of cultural ties with their homeland as well as about the financial support of Ukrainian associations in the region. The issue of protecting the rights of migrant workers $(39.5 \%)$ is important for a third of the respondents. In our view, given the political and economic situation in Ukraine and Poland's need for labor migrants from Ukraine, this issue will become increasingly urgent which requires prompt action by the official authorities of Ukraine.

The leaders of the Ukrainian community were asked to indicate the positive practices of Ukraine's policy towards Ukrainians in Poland. They mentioned: 1) establishment of cooperation with consular institutions; 2) development of cultural ties with Ukraine; and 3) providing local language teachers with opportunities for professional development. On the other hand, among the main drawbacks of the Ukrainian authorities in the implementation of the policy towards Ukrainians in Poland, the following were noted: 1) a complex mechanism for acquiring the status of a foreign Ukrainian; 2) lack of systematic interaction with Ukrainians abroad; 3) lowering the status of the Consulate of Ukraine in Gdańsk; 4) lack of funding for the development and meeting needs of the Ukrainian national minority of the Warmia and Mazury Region from the Ukrainian government. The leaders of the Ukrainian community also noted that at the regional level, opportunities for the development of Ukrainian-Polish cooperation were used to the maximum, and they were more effective than interstate ones. Thus, the Warmia and Mazury Region has established cooperation with some regions of Ukraine (26 agreements on regional cooperation have been concluded). The cooperation with Rivne region and the fact that the region welcomed 180 displaced persons from occupied Donbass were particularly noteworthy.

Recommendations were also formulated for the Ukrainian state structures to increase the effectiveness of the policy towards the Polish Ukrainians, namely: 1) to create an appropriate legislative framework for such work and to apply it systematically. As an example, the Polish authorities' approach to a similar task has been noted here; 2) to organize appropriate departments (sections) on the work with the Diaspora at the Ministry of Foreign Affairs, the Ministry of Culture, diplomatic and consular institutions; 3 ) to create a coordination department under the Ministry of Education and Science of Ukraine which will support the schooling system in the native language of foreign Ukrainians. It should be noted that the Ministry of Foreign Affairs of Ukraine, the 
diplomatic and consular structures, the Ministry of Education and Science of Ukraine and other state structures have numerous departments the activities of which are aimed at fulfilling the above tasks. However the fact that the representatives of the Ukrainian national minority are not familiar with their activities indicates both the low level of information policy of Ukraine and the low efficiency of such structures and the need for their reform.

Consequently, the obtained results provide a basis for answers to the main research problems and let us to state that the main research hypothesis was confirmed. 1.The Ukrainian minority expects greater financial support from the regional authorities, especially since this minority does not have such support from the Ukrainian state as, for example, the German minority from their state; 2 . Leaders of national minority organizations confirm the involvement of regional authorities in the maintenance of culture, language and national identity typical of a given minority; 3 . The regional authorities support not only individual programs of national minorities but also their joint activities; 4 . All the leaders emphasize that they cooperate with the Committee for National and Ethnic Minorities of the Regional Assembly, thus proving that its formation in 1999 was justified; 5. The appointment of the Marshal's Representative of the Warmia and Mazury Region was an important and necessary decision. His work was more appreciated than the work of the Committee for National and Ethnic Minorities; 6 . The activities of the self-government of the Warmia and Mazury Region to reduce inequality of national minorities have taken a model form. Side by side, complementing each other, these two institutions - the Committee and the Representative - are caring for the rights of national minorities.

The data summarized by the results of the research have made it possible to formulate a conclusion about the current state of the Ukrainian national minority in the Warmia and Mazury Region. In particular, there are already established traditions and opportunities for comprehensive development of the Ukrainian national minority. In this region, a unique institutional climate has emerged primarily owing to the activities of the Marshal's Representative for National Minorities and the Committee on National Minorities and Activities. Such an experience is quite effective and, in our opinion, it is advisable to introduce it not only in the practice of other regions of Poland, but also to apply it in other countries of the European region. We should not forget about proper legal and regulatory support for Poland in the protection of the rights and freedoms and meeting the needs of national minorities, including Ukrainian (in socio-political, economic, educational, spiritual and other spheres), which is largely due to Poland's membership in the European Union.

However, there are a number of challenges facing the Ukrainian community in the Warmia and Mazury Region and requiring proper response. They are: strengthening the preventive measures against assimilation of Ukrainians; establishing stable and systematic links between the Ukrainian minority and the state of Ukraine; dicreasing the dependence of the national minority on the political situation; increasing funding 
for cultural, educational and research projects; improving the communication of representatives of the Ukrainian community with each other and with representatives of other national communities; diversification of forms of activity of the Ukrainian community, including the involvement of representatives of the new wave of labor migration, etc. Such tasks can be accomplished only through joint efforts of the Ukrainian community, the Polish society, central and regional government bodies of both the Republic of Poland and Ukraine. The result of such interaction will become a reliable component not only for improving the situation of national minorities in the Republic of Poland and Ukraine, but also for the Ukrainian-Polish strategic partnership in general.

\section{REFERENCES}

Astramowicz-Leyk T. (2002), Europejskie standardy prawa mniejszości narodowych do edukacji a praktyka w regionie Warmii i Mazur, in: Unifikacja i Różnicowanie się wspótczesnej Europy, (eds.) B. Fijałkowska, A. Żukowski, Dom Wydawniczy Elipsa, Warszawa.

Astramowicz-Leyk T. (2016), Działania samorzadu województwa Warmińsko-Mazurskiego na rzecz równego traktowania mniejszości narodowych, 15 sierpnia 2016, http://paperroom.ipsa.org/ papers/paper_64775.pdf (06.07.2019).

Czetyrba-Piszczako M. (2015), Tożsamość kulturowa i identyfikacja językowa Ukraińców Warmii i Mazur, „The Central European Journal of Social Sciences and Humanities”, No. 15: $543-557$.

Dane dotycząe nauczania osób z mniejszości narodowych za lata 2014/2015, Warmińsko-Mazurskie Kuratorium Oświaty w Olsztynie, https://www.ko.olsztyn.pl/ (18.07.2019).

Domagała B. (2009), Ukraińcy na Warmii i Mazurach. Studium procesów asymilacji, Ośrodek Badań Naukowych im. W. Kętrzyńskiego, Olsztyn.

Drozd R., Halczak B. (2010), Dzieje Ukrainców w Polsce w latach 1921-1989, TYRSA, Warszawa.

Dziennik Ustaw (1991), Nr 95, poz. 425 z późn. zm., http://prawo.sejm.gov.pl/isap.nsf/DocDetails. xsp?id=wdu19910950425 (11.07.2019).

Dziennik Ustaw (2005), Nr 17, poz. 14, http://prawo.sejm.gov.pl/isap.nsf/ByYear.xsp?type=WDU\&year $=2005 \& \mathrm{vol}=17(21.06 .2019)$.

Halczak B. (2010), Ukraińcy (po 1989 r.), in: Mniejszości narodowe i etniczne w Polsce po II wojnie światowej, (eds.) S. Dudra, B. Nitschke, Zakład Wydawniczy Nomos, Kraków: 113-127.

Informacja Petnomocnika Marszatka Województwa Warmińsko-Mazurskiego z dnia 10 maja 2016 r., http://olsztyn.uw.gov.pl/index.php?lang=pl (28.07.2019).

Janusz G. (1994), Raport o sytuacji osób należacych do mniejszości narodowych i etnicznych w Polsce, Helsińska Fundacja Praw Człowieka, Warszawa.

Janusz G. (1998), Prawa mniejszości narodowych, etnicznych i językowych, Szkoła Praw Człowieka, Teksty wykładów, Helsińska Fundacja Praw Człowieka, Warszawa.

Janusz G. (2001), Regulacje prawne dotyczace ochrony mniejszości narodowych w Polsce, in: Status prawny mniejszości narodowych w Polsce w świetle Konwencji Ramowej o Ochronie Mniejszości Narodowych, Materiały z konferencji, Warszawa, 23-24 październik 2000, (eds.) S. Łodziński, Wydawnictwo Sejmowe, Warszawa: 115-134.

Konstytucja Rzeczypospolitej Polskiej (1997), Dz. U. 1997, Nr 78 poz. 483, http://prawo.sejm.gov.pl/ isap.nsf/DocDetails.xsp?id=WDU19970780483 (03.09.2019). 
Łodziński S. (1998), Przekroczyć własny cień. Prawne, instytucjonalne oraz społeczne aspekty polityki państwa polskiego wobec mniejszości narodowych w latach 1989-1997, in: Mniejszości narodowe w Polsce. Praktyka po 1989 roku, (eds.) B. Berdychowska, Wydawnictwo Sejmowe, Warszawa.

Pismo Warmińsko-Mazurskiego Kuratora Oświaty z dnia 21 maja 2019 r., https://www.ko.olsztyn. pl/2019/05/21/zarzadzenie-nr-21-warminsko-mazurskiego-kuratora-oswiaty-z-dnia-21maja-2019-r/ (13.06.2019).

Podrucka P., Szkoła J. (2011), Ukraińcy jako diaspora i mniejszość narodowa w Polsce-ujęcie retrospektywne i współczesne, „Zeszyty naukowe ruchu studenckiego”, No. 1: 86-101.

Sakson A. (1998), Stosunki narodowościowe na Warmii i Mazurach 1945-1997, Instytut Zachodni, Poznań.

Sakson A. (2011), Od Kłajpedy do Olsztyna. Wspótcześni mieszkańcy byłych Prus Wschodnich: Kraj Kłajpedzki, Obwód Kaliningradzki, Warmia i Mazury, Instytut Zachodni, Poznań.

Sakson A. (2014), Mniejszość ukraińska na Warmii i Mazurach, in: Mniejszości narodowe i etniczne w Polsce i Europie. Aspekty polityczne i spoteczne, (eds.) A. Sakson, Wydawnictwo Adam Marszałek, Torun.

Załącznik do Uchwały Nr 6/9/00 Zarządu Województwa Warmińsko-Mazurskiego z dnia 25 stycznia 2000 r., par. 43, https://bit.ly/2kskKVg (11.06.2019).

Załącznik do Uchwały Nr X/114/99, par. 23 p. 8 z dnia 14 października 1999 r., https://bitly.su /2A3g9 (18.09.2019).

Євтух В., Трощинський В., Попок А. (2005), Закордонне украйнство. Навчальний посібник, ВІК, Київ.

Лоза П. (2018a), 38 україниів перемогли у місиевих виборах у Польщі, 25 жовтня 2018, http:// www.nasze-slowo.pl/news/32-ukrainci-peremogli/ (12.06.2019).

Лоза П. (2018b), Украӥнські кандидати у виборах до сеймику Вармінсько-Мазурського воєводства, 11 липня 2018, http://www.nasze-slowo.pl/news/ukrainski-kandidati-u-viborah-dosejmiku-varminsko-mazurskogo-voievodstva/ (3.07.2019).

Лоза П. (2019), Феномен об'єднання через різноманітність, 21 квітня 2019, https://www.naszeslowo.pl/fenomen-ob-dnannya-cherez-riznomanitnist/ (18.07.2019).

Наш вибір (2019), Скільки украӥнців живе в Польщчі, 11 березня 2019, https://naszwybir.pl/ skilky-ukrayintsiv-zhyve-v-polshhi-nove-doslidzhennya/ (12.07.2019).

Турчин Я. (2014), Українська держава та закордонне украйнство в Польщі: особливості взаємодіï, „Українська національна ідея: реалії та перспективи розвитку”, №. 26: 149-155.

\begin{abstract}
The research aims at presenting and exploring the mechanisms for protection of the rights of national minorities (based on the example of Ukrainian minority) in the Warmia and Mazury Region of the Republic of Poland. The research hypothesis is based on the statement that in fact the protection of rights of national minorities at the level of the Warmia and Mazury Region could be treated as a model, and thus implemented in other regions in Poland, or even in other countries facing the problems related to the protection of national and ethnic minorities. The main research problems are addressed within the questions: how is Ukrainian minority distributed in the studied region?; What are the state and local government institutions working for national minorities in the studied region of Poland?; What activities do these institutions undertake to ensure equal treatment of national minorities and provision for their rights?; How are
\end{abstract}


these activities assessed by organizations/representatives of the Ukrainian national minority? The leading research method was the institutional and legal one. The research also contained the interviewing method as well as the focus group interview. Obtained results of the study confirmed the research hypothesis. It turned out that the Warmia and Mazury Region has created an effective institutional environment for the development of national minorities, including the Ukrainian one. It was possible thanks to the activity of the only Polish Plenipotentiary of the Marshal for national minorities and also the only National and Ethnic Minorities Committee of the Regional Council in Poland.

Keywords: Ukrainian national minority, protection of the rights of national minorities, the Warmia and Mazury Region

\section{INSTYTUCJONALNO-PRAWNE MECHANIZMY OCHRONY PRAW MNIEJSZOŚCI UKRAIŃSKIEJ W WOJEWÓDZTWIE WARMIŃSKO-MAZURSKIM}

\section{STRESZCZENIE}

Celem przeprowadzonych badań było ukazanie i analiza mechanizmów ochrony praw mniejszości narodowych (na przykładzie mniejszości ukraińskiej) w województwie warmińsko-mazurskim, wchodzącym w skład terytorium Polski. Jako hipotezę badawczą przyjęto stwierdzenie, że w praktyce ochrona praw mniejszości narodowych na poziomie województwa warmińsko-mazurskiego jest modelowa, a tym samym może być realizowana także w innych województwach w Polsce, a nawet w innych państwach, w których istnieją problemy związane $\mathrm{z}$ ochroną mniejszości narodowych i etnicznych. Główne problemy badawcze zawierały się w pytaniach o to: jak jest rozmieszczona w badanym województwie mniejszość ukraińska?; jakie są w badanym regionie Polski instytucje państwowe i samorządowe działające na rzecz mniejszości narodowych?; jaką działalność przejawiają te instytucje na rzecz równego traktowania mniejszości narodowych i zagwarantowania ich praw? jak te działania oceniają przedstawiciele organizacji mniejszości ukraińskiej? Wiodącą metodą badawczą była metoda instytucjonalno-prawna, a także zastosowano ankietę i wywiad fokusowy. W wyniku badań potwierdzono hipotezę badawczą. Okazało się, że w województwie warmińsko-mazurskim stworzono efektywny, instytucjonalny klimat dla rozwoju mniejszości narodowych, w tym ukraińskiej. Stało się to możliwe dzięki działalności jedynego w Polsce pełnomocnika marszałka województwa do spraw mniejszości narodowych i również jedynej w Polsce Komisji Mniejszości Narodowych i Etnicznych sejmiku tegoż województwa.

Słowa kluczowe: mniejszość ukraińska, ochrona praw mniejszości narodowych, województwo warmińsko-mazurskie 